\title{
BMJ Open RCT of the effect of berryfruit polyphenolic cultivar extract in mild steroid-naive asthma: a cross-over, placebo-controlled study
}

Sharon Power, ${ }^{1,2}$ Mathew Williams, ${ }^{1}$ Alex Semprini, ${ }^{1,2,3}$ Claire Munro, ${ }^{4}$ Rachel Caswell-Smith, ${ }^{1,2,3}$ Janine Pilcher, ${ }^{1,2,3}$ Mark Holliday, ${ }^{1}$ James Fingleton, ${ }^{1,2,3}$ Jacquie Harper, ${ }^{5}$ Roger Hurst, ${ }^{6}$ Mark Weatherall, ${ }^{2,4}$ Richard Beasley, ${ }^{1,2}$ Irene Braithwaite ${ }^{1,2,3}$

To cite: Power S,

Williams M, Semprini A, et al. RCT of the effect of berryfruit polyphenolic cultivar extract in mild steroid-naive asthma: a cross-over, placebocontrolled study. BMJ Open 2017;7:e013850 doi:10.1136/bmjopen-2016013850

- Prepublication history and additional material is available. To view please visit the journal (http://dx.doi.org/ 10.1136/bmjopen-2016013850).

Received 11 August 2016 Revised 31 January 2017 Accepted 2 February 2017

CrossMark

For numbered affiliations see end of article.

Correspondence to Dr Irene Braithwaite; Irene.Braithwaite@mrinz.ac.nz

\section{ABSTRACT}

Objective: There is preclinical evidence that consumption of berryfruit extract may reduce chronic airways inflammation and modify airway remodelling in allergen-induced models of lung inflammation. We investigated the effect of berryfruit extract on the fractional expired nitric oxide (FeNO), a biomarker of eosinophilic airways inflammation, in adults with steroid-naïve asthma.

Design: Randomised placebo-controlled cross-over double-blind trial.

Setting: Single-centre community-based trial.

Participants: 28 steroid-naive mild asthmatics with Feno $>40$ ppb, of whom 25 completed both study interventions.

Interventions: Participants were randomised to receive, according to the cross-over design, $100 \mathrm{mg}$ berryfruit polyphenolic extract (BFPE) or placebo for 4 weeks, with a 4-week washout period between the interventions.

Primary outcome measure: The primary outcome variable was FeNO at 4 weeks, analysed by a mixed linear model, with a random effect for participant and baseline FeNo as a covariate.

Results: The mean (SD) natural logarithm transformed (In) FeNO after 4 weeks of treatment for the BFPE and placebo groups was $4.28(0.47)$ and $4.22(0.47)$, respectively. The paired change from baseline mean (SD) BFPE minus placebo In FeNO was -0.03 (0.39), $N=25$. The mixed linear model estimate, with baseline covariate adjustment, difference in In FeNO, was $-0.002(95 \% \mathrm{Cl}-0.15$ to 0.14$), p=0.98$. This is equivalent to a ratio of geometric mean FeNO of 1.0 (95\% Cl 0.86 to 1.15).

Conclusions: In steroid-naïve participants with mild asthma and elevated FeNO, there was no effect of BFPE on FeNO, a biomarker of eosinophilic airways inflammation. Caution is required in the extrapolation of apparent benefit in murine models of lung eosinophilia to clinical efficacy in patients with asthma.

Trial registration number: ANZCTR: 12613000451707; Results.

\section{Strengths and limitations of this study}

- This was a cross-over, double-blind, randomised, placebo-controlled trial.

- Participants were steroid-naive patients with asthma with elevated fractional expired nitric oxide, maximising the likelihood of a response to the properties of berryfruit polyphenolic extract.

- The study participants' asthma may not have been severe enough to detect clinically significant improvements in lung function or quality of life

\section{INTRODUCTION}

The prevalence of asthma has markedly increased in many countries throughout the world over the past 50 years leading to asthma becoming one of the most common non-communicable diseases in children and adults. ${ }^{12}$ The reasons for these global trends are poorly understood. Furthermore, there are no primary prevention strategies that have undergone scrutiny in randomised controlled trials that have provided sufficient evidence to lead to widespread implementation in clinical practice. ${ }^{3}$ This has led to the consideration of novel strategies, emanating from epidemiological observations and animal experiments, from which proof-ofconcept clinical trials can be undertaken in humans. ${ }^{4}$ In particular, dietary factors may contribute to the pathogenesis of asthma.

There are a number of non-experimental studies exploring the association between fruit consumption and respiratory symptoms and incidence of lung diseases such as asthma in non-experimental studies. ${ }^{5-10}$ Consumption of kiwifruit and citrus fruits is associated with a lower prevalence of asthma in children $^{11}$ and fruit and vegetable intake 
is also positively associated with reduced risk of asthma in adults. ${ }^{12} 13$ High fruit juice consumption has been associated with an increased risk of asthma in children. ${ }^{8}$ This association may be due to high excess fructose fruit juices such as apple, rather than other juices low in excess fructose such as orange, which may be protective. ${ }^{9}$ A possible mechanism for the variation in these findings is that consumption of fruits high in excess free fructose leads to the formation of proinflammatory advanced glycation end products (AGE) in the intestine, which are absorbed into the circulation, causing a systemic immune response. Since the lungs have a high concentration of AGE receptors, ${ }^{14}$ pulmonary tissue may be more affected by this mechanism than other organs. Until now, results of more robust study designs, such as randomised controlled trials, offer limited support to the hypothesis that specific fruit supplementation may be effective for asthma. ${ }^{15-19}$

Asthma is a chronic inflammatory disease of the airways ${ }^{20}$ and fruit-derived polyphenolic flavonoid compounds such as anthocyanins and proanthocyanins attenuate lung inflammation in preclinical studies ${ }^{21-23}$ and have immune modulatory actions. ${ }^{24}$ Berryfruits, as well as being low in excess free fructose,${ }^{25}$ contain high amounts of anthocyanins and proanthocyanins, and in vitro studies indicate that they have the potential to reduce eosinophilic inflammation in asthma. ${ }^{26}$ In vivo feeding studies using ovalbumin-induced chronic lung inflammation models in mice show that consumption of a specific berry variety decreases numbers of mucus-producing cells and reduces collagen deposition, suggesting an effect on airway remodelling. ${ }^{27}$

As many as $40 \%$ of asthmatics use complementary and alternative medicine treatments. ${ }^{28}$ Research that identifies evidence of efficacy or lack of efficacy of these products is of interest to those with and those treating asthma.

The objective of this study was to assess the effect of a berryfruit polyphenolic extract (BFPE) in mild asthma. Our hypothesis in this study is that BFPE reduces fractional expired nitric oxide (FeNO), a biomarker of eosinophilic airway inflammation, which is elevated in patients with asthma and is highly sensitive to antiinflammatory inhaled corticosteroid treatment. ${ }^{29-34}$ We also investigated possible effects on airways resistance, serum eosinophils and asthma control over the same time period.

\section{METHODS}

\section{Participants and methods}

This was a cross-over, double-blind, randomised, crossover, placebo-controlled trial in 28 participants with mild asthma to compare FeNO between use of BFPE and a placebo. Eligible participants were aged between 18 and 75 years, with a doctor's diagnosis of asthma, were steroid-naive (no inhaled or oral corticosteroid in the past 90 days), and had an FeNO of $>40$ ppb. Participants were excluded if they were unable to provide informed consent, unable or unwilling to comply with study procedures (including not consuming confounding foodstuffs during study periods), pregnant, trying to conceive, or had a known hypersensitivity to berryfruits.

Participants were recruited from an existing database within the Medical Research Institute of New Zealand (MRINZ). Contact was made via telephone and participants were invited to attend the MRINZ for screening (visit 1).

The trial was approved by the New Zealand Health and Disability Ethics Committee (Wellington) and written informed consent was obtained from all the trial participants.

\section{Randomised treatments}

Participants were randomised to receive either encapsulated BFPE $1000 \mathrm{mg}$ daily or matching placebo capsules for 4 weeks, followed by a 4 -week washout period, and then the other randomised treatment for 4 weeks. The BFPE and matching placebo tablets were supplied by Plant \& Food Research.

\section{Randomisation}

The randomisation schedule was generated by the study statistician, independently of the investigators undertaking the visits, using a computer-generated random number sequence. To maintain blinding, bottles of tablets were placed in numbered opaque bags by non-clinical investigators. On randomisation, the bagged tablets were given to the participant by clinical investigators according to the randomisation schedule. Compliance counts were undertaken by non-clinical investigators.

\section{Study design}

The study comprised four visits $\left(\mathrm{V}_{1}-\mathrm{V}_{4}\right)$ followed by a final phone call 1 week after completion of the second intervention (figure 1). At $\mathrm{V}_{1}$, participants were randomised in a ratio of $1: 1$ to the order in which they received 28 days of treatment with BFPE or placebo. There was a washout period between the two interventions of 28 days. This washout period was chosen as it is double the length of time for FeNO to return to baseline levels after cessation of inhaled corticosteroid treatment. ${ }^{35}$ Participants were requested to refrain from consuming berry-containing foods and drinks for the entire duration of the study.

During each 4-week intervention period, participants self-completed a questionnaire of their compliance in terms of consumption of foods and drinks which they had been asked to avoid, which were provided on a list (see online supplementary appendix 1). The amount, date and food type were documented and returned on subsequent visits $\left(\mathrm{V}_{2} / \mathrm{V}_{4}\right)$. Investigational product and placebo compliance were captured via a capsule count performed at the end of each intervention period $\left(\mathrm{V}_{2} / \mathrm{V}_{4}\right)$. 


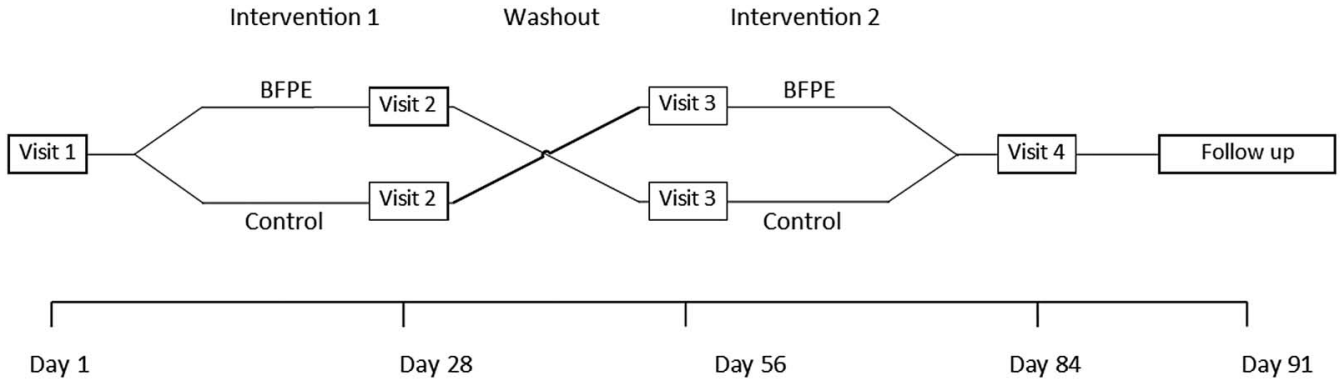

\section{Measurements}

At each visit, measurements were made of the FeNO, lung function and peripheral blood eosinophil count, and the asthma control questionnaire $(\mathrm{ACQ})^{36}$ was administered. The FeNO concentration was measured as per the American Thoracic Society (ATS) guidelines ${ }^{37}$ via an online nitric oxide monitor (NIOX, Aerocrine $\mathrm{AB}$, Solna, Sweden). Forced expiratory volume in $1 \mathrm{~s}$ $\left(\mathrm{FEV}_{1}\right)$, specific airways conductance and resistance (sRaw/sGaw, measures of large airway function) and maximum mid-expiratory flow 25-75 $\left(\mathrm{MMEF}_{25-75}\right.$, a measure of small airway function) were measured by body plethysmograph (Masterlab 4.5 and 4.6 Erich-Jaeger, Wurzberg, Germany) according to ATS guidelines. ${ }^{38}$ Venepuncture was carried out to obtain a full blood count for measurement of peripheral blood eosinophil count. All the procedures were undertaken at baseline and repeated at each visit at time points of 4,8 and 12 weeks.

\section{Outcome variables}

The primary outcome variable was the FeNO. Secondary outcomes included ACQ-5 score, $\mathrm{FEV}_{1}, \mathrm{MMEF}_{25-75}$, sRaw, sGaw and peripheral blood eosinophil count.

\section{Statistical analysis}

The primary analysis was a mixed linear model with the FeNO as a response variable, the treatments, BFPE and placebo, and baseline FeNO, before each cross-over treatment, as fixed effects. To account for the cross-over design, participants were treated as random effects. The FeNO was natural logarithm transformed (ln) for analysis purposes. Exponentiation of the difference in $\mathrm{ln}$ FeNO is interpreted as the ratio of geometric mean $\mathrm{FeNO}$ between two randomised groups.

SAS V.9.2 was used and the statistical model is available in the online supplementary material.

\section{Sample size}

The sample size calculation was based on a paired t-test because we could identify no publications that reported variance components for a mixed linear model that was planned for the primary analysis. A sample size of 24 had $80 \%$ power, $\alpha 5 \%$, to detect a difference in $\ln \mathrm{FeNO}$ of 0.227 , equivalent to a ratio of geometric mean values of 1.25 , based on the paired SD of 0.38 for the difference in $\ln \mathrm{FeNO}$ at two visits in a group of steroid-naïve asthmatics taking a placebo in a study recently conducted by the MRINZ. ${ }^{39}$ This is slightly larger than the ATS-defined minimally important decrease of $20 \%$ in FeNO for individuals with an FeNO 50 ppb or greater. ${ }^{34}$ The recruitment target was 28 participants, allowing for a $15 \%$ withdrawal rate.

\section{RESULTS}

Between May and August 2013, 220 patients were approached for inclusion in the study. Following the exclusion of 97 (44\%) who declined participation, 41 (19\%) who were treated with steroids, 54 (25\%) with comorbidities and other exclusion criteria, there were 28 (13\%) participants who were randomised. There were three withdrawals, two due to worsening asthma (one during the placebo intervention and one during washout after BFPE treatment), and one because of renal calculi requiring surgical intervention (during the washout after BFPE treatment; figure 2).

The characteristics of the 28 randomised participants are shown in table 1 . The participants had a mean age of 42 , were predominantly male $(61 \%)$ and had a mean baseline FeNO concentration of $76.9 \mathrm{ppb}$. The mean $\mathrm{FEV}_{1}$ was $100 \%$ predicted and mean ACQ-5 was 0.65 .

\section{Primary outcome variable}

FeNO had a skewed distribution and the natural logarithm transformation was used in the analysis. The mean (SD) In FenO after 4 weeks of treatment for the BFPE $(\mathrm{N}=28)$ and placebo $(\mathrm{N}=25)$ groups was $4.28(0.47)$ and 4.22 (0.47), respectively (table 2, figure 3 ). The paired change from baseline mean (SD) BFPE minus placebo (In) FenO was $-0.03(0.39), \mathrm{N}=25$. The mixed linear model estimate, with baseline covariate adjustment, difference in In FeNO was -0.002 (95\% CI -0.15 to 0.14 ), $\mathrm{p}=0.98$. This is equivalent to a ratio of geometric mean FeNO of 1.0 (95\% CI 0.86 to 1.15 ). The median values for $\mathrm{FeNO}$ at baseline and 4 weeks for BFPE were 68.0 and $73.5 \mathrm{ppb}$ and for placebo 63.0 and $67.0 \mathrm{ppb}$.

\section{Secondary outcome variables}

The estimates and associated CIs for the treatmentassociated differences, BFPE versus placebo, in the 


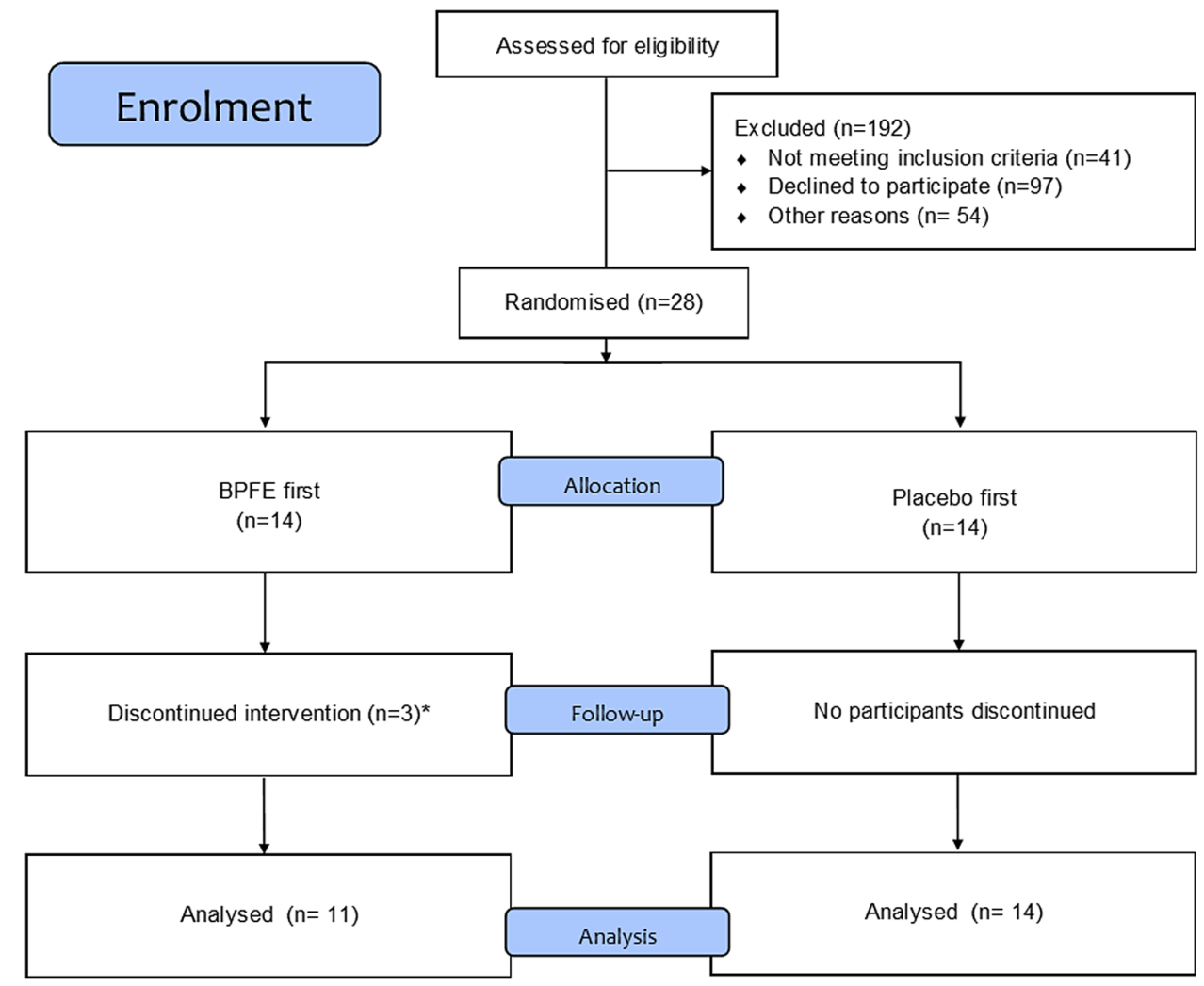

Figure 2 Participant inclusion/exclusion pathway. BFPE, berryfruit polyphenolic extract.

\begin{tabular}{|c|c|c|}
\hline Variable $\mathrm{N}=28$ & Mean (SD) & N (\%) \\
\hline Age (years) & $42.3(11.8)$ & \\
\hline BMI $\left(\mathrm{kg} / \mathrm{m}^{2}\right)$ & $26.7(5.1)$ & \\
\hline Male sex & & $17(61 \%)$ \\
\hline \multicolumn{3}{|l|}{ Ethnicity } \\
\hline European & & $23(82 \%)$ \\
\hline Māori & & $1(4 \%)$ \\
\hline Other & & $4(14 \%)$ \\
\hline FeNO (ppb) & 76.9 (41.48) & \\
\hline $\mathrm{FEV}_{1} \%$ predicted & $100.2(15.7)$ & \\
\hline MMEF $_{25-75}(\mathrm{~L} / \mathrm{min})$ & $156.3(60.5)$ & \\
\hline sRaw (kPa/s) & $1.16(0.42)$ & \\
\hline sGaw (kPa/s) & $0.96(0.29)$ & \\
\hline$A C Q-5$ & $0.65(0.58)$ & \\
\hline Eosinophils $\left(\times 10^{\wedge^{9} \mathrm{~L}}\right)$ & $0.33(0.19)$ & \\
\hline \multicolumn{3}{|c|}{$\begin{array}{l}\text { ACQ-5, asthma control questionnaire-5; BMI, body mass index; } \\
\text { FeNO, fraction of exhaled nitric oxide; FEV } \text {, forced expiratory }_{\text {volume in } 1 \mathrm{~s} \text {; } \text { MMEF }_{25-75} \text {, maximal mid expiratory flow; sGaw, }} \text { specific airway conductance; sRaw, specific airway resistance. }\end{array}$} \\
\hline
\end{tabular}

secondary outcome variables: $\mathrm{FEV}_{1}, \mathrm{MMEF}_{25-75}$, sRaw and sGaw after 4 weeks of treatment are shown in table $3 . \mathrm{MMEF}_{25-75}$ was the only measure with a statistically significant difference and this favoured placebo. Asthma control remained stable throughout the intervention and washout periods with no significant difference in ACQ-5 between randomised treatment groups. There was no change from baseline in peripheral blood eosinophil count with 4 weeks of treatment of BFPE and no difference between BFPE and placebo treatments.

There was a high rate of recorded medication compliance with 23/28 (82\%) participants $>95 \%$ compliant with BFPE and 19/25 (75\%) >95\% compliant with the placebo. There was no significant difference in compliance between the two treatment groups, $\mathrm{p}=0.09$. Breaches in specified non-allowed food and drink consumption throughout the study were deemed as minor, with 21/28 $(75 \%)$ patients consuming small amounts of berry-containing foods during the period of the study. The highest amount was three blueberry muffins consumed over the duration of the entire study by one participant.

The most frequent adverse event was headache, which occurred in half of the participants. There were 20 reports of headaches, 6 occurring during BFPE consumption, 6 during placebo and 8 during the washout phase.

\section{DISCUSSION}

This randomised placebo-controlled cross-over trial did not find evidence for an effect of BFPE on FeNO, a measure of eosinophilic airways inflammation, in mild steroid-naïve asthma. As a result, the findings of chronic anti-inflammatory and remodelling effects of BFPE in animal in vivo trials were not confirmed in this human study in asthma. ${ }^{27}$

There are a number of methodological issues that are relevant to the interpretation of the study findings. First, 
Table 2 FeNO measurements (median (IQR))* before and after 4 weeks of treatment with BFPE and placebo

\begin{tabular}{|c|c|c|c|c|c|c|c|}
\hline & \multicolumn{2}{|l|}{ BFPE } & \multicolumn{2}{|l|}{ Placebo } & \multirow{2}{*}{$\begin{array}{l}\text { Difference in mean } \\
\text { In FeNO, BFPE } \\
\text { minus placebo† }\end{array}$} & \multirow{2}{*}{$\begin{array}{l}\text { Ratio mean In } \\
\text { FeNO, BFPE vs } \\
\text { placeboł‡ }\end{array}$} & \multirow[b]{2}{*}{ p Value } \\
\hline & $\begin{array}{l}\text { Baseline } \\
(\mathrm{n}=28) \mathrm{ppm}\end{array}$ & $\begin{array}{l}4 \text { weeks } \\
(n=28) p p m\end{array}$ & $\begin{array}{l}\text { Baseline } \\
(n=26) \text { ppm }\end{array}$ & $\begin{array}{l}4 \text { weeks } \\
(n=25) \text { ppm }\end{array}$ & & & \\
\hline Median & 68.0 & 73.5 & 63.0 & 67.0 & & & \\
\hline IQR & 50.5 to 96.5 & 49.5 to 112.0 & 52.0 to 98.0 & 53.0 to 94.0 & & & \\
\hline $\begin{array}{l}\text { Ln§ mean } \\
\text { (SD) } \\
(95 \% \text { Cl) }\end{array}$ & $\begin{array}{l}4.27 \\
(0.44)\end{array}$ & $\begin{array}{l}4.28 \\
(0.47)\end{array}$ & $\begin{array}{l}4.24 \\
(0.38)\end{array}$ & $\begin{array}{l}4.22 \\
(0.47)\end{array}$ & -0.002 & 1.0 & 0.98 \\
\hline
\end{tabular}

FeNO had a skewed distribution and the natural logarithm transformation (In) was used in the analysis of comparison between treatments.

${ }^{*} \mathrm{IQR}$.

†Mixed linear model with baseline covariate.

\#Exponent of the difference in natural logarithms.

§Ln: natural logarithm.

BFPE, berryfruit polyphenolic extract; FeNO, fraction of exhaled nitric oxide.

Figure 3 Logarithm FeNO values for each participant throughout both intervention arms. FeNO, fraction of exhaled nitric oxide.

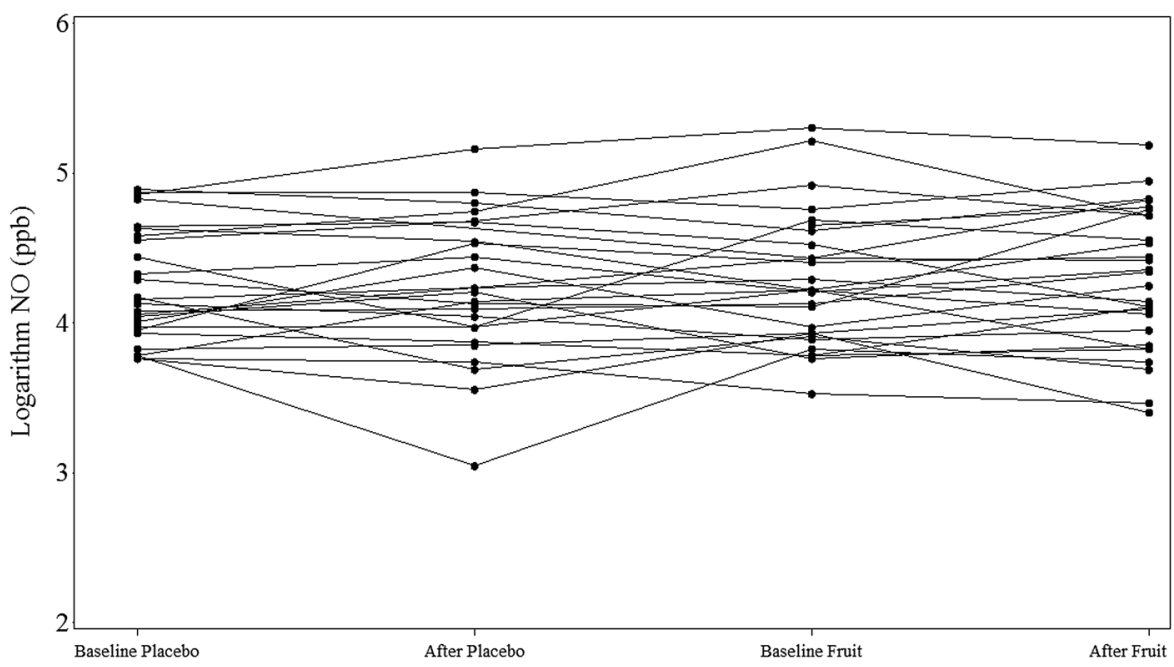

Table 3 Secondary outcome measures (mean (SD)) before and after 4 weeks treatment with BFPE or placebo

\begin{tabular}{|c|c|c|c|c|c|}
\hline \multirow[b]{2}{*}{ Variable } & \multicolumn{2}{|l|}{ BFPE } & \multicolumn{2}{|l|}{ Placebo } & \multirow[b]{2}{*}{$\begin{array}{l}\text { Difference, BFPE minus } \\
\text { placebo* }(95 \% \mathrm{CI}) \text {, p Value }\end{array}$} \\
\hline & $\begin{array}{l}\text { Baseline } \\
(n=28)\end{array}$ & $\begin{array}{l}4 \text { weeks } \\
(n=28)\end{array}$ & $\begin{array}{l}\text { Baseline } \\
(n=26)\end{array}$ & $\begin{array}{l}\text { Post } 4 \text { weeks } \\
(n=25)\end{array}$ & \\
\hline $\mathrm{FEV}_{1}(\mathrm{~L})$ & $3.61(1.06)$ & $3.54(0.98)$ & $3.56(1.00)$ & $3.53(1.06)$ & $-0.07(-0.20$ to 0.06$), p=0.26$ \\
\hline $\begin{array}{l}\mathrm{MMEF}_{25-75} \\
(\mathrm{~L} / \mathrm{min})\end{array}$ & $160.5(63.0)$ & $152.8(60.6)$ & $155.5(60.1)$ & $159.4(67.3)$ & $-11.8(-22.6$ to -1.0$), p=0.034^{*}$ \\
\hline sRaw (kPa/s) & $1.12(0.41)$ & $1.22(0.38)$ & $1.21(0.40)$ & $1.18(0.44)$ & $0.09(-0.06$ to 0.24$), p=0.22$ \\
\hline sGaw (kPa/s) & $0.99(0.30)$ & $0.90(0.25)$ & $0.91(0.27)$ & $0.94(0.28)$ & $-0.07(-0.18$ to 0.03$), p=0.17$ \\
\hline$A C Q-5$ & $0.74(0.61)$ & $0.77(0.61)$ & $0.62(0.57)$ & $0.70(0.76)$ & $-0.06(-0.37$ to 0.25$), p=0.72$ \\
\hline Eosinophils $\left(\times 10^{\wedge^{9} L}\right)$ & $0.31(0.14)$ & $0.32(0.18) \dagger$ & $0.33(0.21)$ & $0.30(0.16)$ & $0.01(-0.05$ to 0.08$), p=0.69$ \\
\hline
\end{tabular}

FeNO was the primary outcome variable as it is a validated biomarker of eosinophilic airways inflammation mediated by the T helper 2 (Th2) pathway. ${ }^{29} 32{ }^{34} \mathrm{In}$ steroid-naïve patients with mild asthma, $\mathrm{FeNO}$ is correlated with bronchial hyper-responsiveness, a fundamental physiological measure of asthma severity. ${ }^{40} \mathrm{FeNO}$ is highly sensitive to the effects of Inhaled corticosteroid
(ICS) and therefore highly responsive to antiinflammatory therapy. ${ }^{33} 34$ For this reason, we studied ICS-naïve participants who had not taken ICS or oral steroids in the previous 90 days. Participants were also required to have a raised $\mathrm{FeNO}$ at baseline, to ensure that active airways inflammation was present, and therefore potentially amenable to anti-inflammatory 
treatment. FeNO measurements are also simple and non-invasive and, as shown in this study, are stable over long periods in mild asthma, providing a stable baseline.

However, the drawback of the inclusion of steroid-naïve participants with mild asthma is that it limited the ability to investigate the effects of BFPE on lung function and ACQ as most of the participants had normal lung function and well-controlled asthma. The mean baseline $\mathrm{FEV}_{1}$ was $100 \%$ predicted and the mean ACQ-5 score was 0.65 , indicating that the study participants' asthma may not have been severe enough to detect clinically significant improvements in lung function or quality of life. Our study does not rule out an effect of BFPE on lung function and asthma control in patients with moderate-to-severe asthma.

The study was placebo-controlled with the two treatments prepared in identical capsules. The $1000 \mathrm{mg}$ dose of BFPE was based on animal data in which $10 \mathrm{mg} / \mathrm{kg}$ berryfruit extract was effective in reducing chronic inflammatory changes in the airways. ${ }^{27}$ Treatments were continued for 4 weeks based on the animal data showing effects in a chronic model with 30 days of dosing. ${ }^{27}$ The cross-over design allowed participants to serve as their own controls, minimising variability and increasing power to detect any changes in the primary outcome measure. There was also good integrity of the data set, as depicted by the closely matched baseline variables at the start of each intervention period, indicating good reproducibility. This study was designed partly as a mechanistic one addressing whether airways inflammation might be reduced by BPFE and the relevant variable for this is the FeNO. The CI for the change in ratio of geometric mean FeNO was well inside the prespecified clinical difference. ${ }^{34}$ For the secondary outcome variables, the confidence limits for change in $\mathrm{FEV}_{1}$ and $\mathrm{ACQ}$ were well within previous established clinically important differences, ${ }^{36}{ }^{41}$ making type II errors unlikely. Clinically important changes in the remaining secondary outcome variables are not well established. There was some evidence of a slightly lower $\mathrm{MMEF}_{25-75}$ after BFPE compared with the placebo; however, this result should be interpreted with caution as we did not control for multiple measurements and this could be the result of type 1 error.

To aid compliance and reduce introduction of other polyphenolic-containing foods and drinks, the study was performed outside the berryfruit season. This appeared to assist in maintaining a very low reported non-approved consumption of polyphenolic-containing foods and drinks.

The animal in vivo boysenberry feeding studies on which this trial was based conferred some benefit with reduction in airways inflammation and modulation of the Th2 pathway in chronic allergen-driven models of airways inflammation in mice. ${ }^{27}$ There was evidence of decreased collagen deposition, suggesting an effect on airways remodelling. It has been proposed that these effects may be due to modulation of the functional phenotype of alternatively activated macrophages in the lung, and associated increased expression of profibrolytic matrix metalloproteinase-9 protein. Furthermore, in vitro studies of lung alveolar epithelial cells have shown that blackcurrant polyphenolic extracts suppress secretion of eotaxin 3, an important chemoattractant responsible for eosinophil recruitment into airways. ${ }^{26}$ However, our data did not support the replication of these effects to human individuals with asthma.

This poor translation of positive outcomes from laboratory-based and animal models to human disease is not uncommon, particularly surrounding the extrapolation of apparent benefit in murine models of lung eosinophilia to clinical outcomes in patients with asthma. ${ }^{42-46}$ This is not surprising as chronic asthma is a disease unique to humans and there are fundamental anatomical, physiological and immunological differences between the species. In contrast to humans, mice are born with fully developed lungs, have far fewer orders of airways branching, a large airway epithelium that is not fully stratified, lack submucosal glands beyond the trachea and most mouse airways do not contain smooth muscle bundles. Murine airways are also smaller than humans in absolute terms but are relatively wider, providing challenges to the accurate measurement and definition of physiological parameters of disease and response to treatment. The allergic inflammation in mouse airways is predominantly parenchymal and vascular, rather than being generally restricted to the conducting airways as in human disease and chronic allergen models do not lead to increases in airway smooth muscle, a hallmark of asthma. As a result, the reasons underlying the failure to translate the murine findings ${ }^{24}$ for this berryfruit supplement into this human randomised controlled trial are likely to be multifactorial and support recommendations to improve murine systems to more closely reflect the disease for which they are used as models. ${ }^{42-46}$

In conclusion, in steroid-naïve participants with mild asthma and elevated FeNO, there was no effect of BFPE on FeNO, a biomarker of eosinophilic airways inflammation.

\section{Author affiliations}

${ }^{1}$ Medical Research Institute of New Zealand, Wellington, New Zealand ${ }^{2}$ Capital and Coast District Health Board, Wellington, New Zealand

${ }^{3}$ Victoria University of Wellington, Wellington, New Zealand

${ }^{4}$ University of Otago, Wellington, New Zealand

${ }^{5}$ Malaghan Institute of Medical Research, Wellington, New Zealand

${ }^{6}$ The New Zealand Institute for Plant \& Food Research, Palmerston North, New Zealand

Contributors RB, IB, JF, JH, MH, RH, MWe and MWi were involved in study concept and design. IB, RC-S, CM, JP, SP and MWi were involved in acquisition of data. RB, IB, SP and AS were involved in drafting of the manuscript. All authors were involved in critical revision of the manuscript for important intellectual content. MWe was involved in statistical analysis. All authors provided administrative, technical and material support. SP and MWi were involved in study supervision..

Funding This research was funded by a New Zealand Ministry of Business, Innovation and Employment Grant (Contract C11X1002), awarded to the New Zealand Institute of Plant and Food Research. The Medical Research Institute of New Zealand is supported by Health Research Council of New Zealand Independent Research Organisation funding (HRC 14/1002). 
Competing interests None declared.

Ethics approval NZ Health and Disability Committee.

Provenance and peer review Not commissioned; externally peer reviewed.

Data sharing statement Patient-level data are available from the corresponding author on request. The presented data are anonymised and the risk of identification is low.

Open Access This is an Open Access article distributed in accordance with the Creative Commons Attribution Non Commercial (CC BY-NC 4.0) license, which permits others to distribute, remix, adapt, build upon this work noncommercially, and license their derivative works on different terms, provided the original work is properly cited and the use is non-commercial. See: http:// creativecommons.org/licenses/by-nc/4.0/

\section{REFERENCES}

1. Eder W, Ege MJ, von Mutius E. The asthma epidemic. $N$ Engl J Med 2006;355:2226-35

2. Masoli M, Fabian D, Holt S, et al. The global burden of asthma: executive summary of the GINA dissemination committee report. Allergy 2004;59:469-78.

3. Beasley R, Semprini A, Mitchell EA. Risk factors for asthma: is prevention possible? Lancet 2015;386:1075-85.

4. Beasley R, Crane J, Lai CK, et al. Prevalence and etiology of asthma. J Allergy Clin Immunol 2000;105:S466-72.

5. Ellwood P, Asher MI, Björkstén B, et al. Diet and asthma, allergic rhinoconjunctivitis and atopic eczema symptom prevalence: an ecological analysis of the International Study of Asthma and Allergies in Childhood (ISAAC) data. Eur Respir J 2001;17: 436-43.

6. Nagel G, Weinmayr G, Kleiner A, et al. Effect of diet on asthma and allergic sensitisation in the International Study on Allergies and Asthma in Childhood (ISAAC) Phase Two. Thorax 2010;65: 516-22.

7. Rosenlund H, Kull I, Pershagen G, et al. Fruit and vegetable consumption in relation to allergy: disease-related modification of consumption? J Allergy Clin Immunol 2011;127:1219-25.

8. Berentzen NE, Van Stokkom VL, Gehring U, et al. Associations of sugar-containing beverages with asthma prevalence in 11-year-old children: the PIAMA birth cohort. Eur J Clin Nutr 2015;69:303-8.

9. DeChristopher LR, Uribarri J, Tucker KL. Intakes of apple juice, fruit drinks and soda are associated with prevalent asthma in US children aged 2-9 years. Public Health Nutr 2016;19:123-30.

10. Uribarri J, Woodruff S, Goodman S, et al. Advanced glycation end products in foods and a practical guide to their reduction in the diet. J Am Diet Assoc 2010;110:911-16.e12.

11. Forastiere F, Pistelli $R$, Sestini $P$, et al. Consumption of fresh fruit rich in vitamin $C$ and wheezing symptoms in children. SIDRIA Collaborative Group, Italy (Italian Studies on Respiratory Disorders in Children and the Environment). Thorax 2000;55:283-8.

12. Shaheen SO, Sterne JAC, Thompson RL, et al. Dietary antioxidants and asthma in adults-population-based case-control study. Am J Respir Crit Care Med 2001;164:1823-8.

13. Romieu I, Varraso R Avenel V. Fruit and vegetable intakes and asthma in the E3N study. Thorax 2006;61:209-15.

14. Buckley ST, Ehrhardt C. The receptor for advanced glycation end products (RAGE) and the lung. BioMed Research International, 2010.

15. McKeever TM, Britton J. Diet and asthma. Am J Respir Crit Care Med 2004;170:725-9.

16. Fogarty $A W$, Antoniak M, Venn AJ, et al. A natural experiment on the impact of fruit supplementation on asthma symptoms in children. Eur Respir J 2009;33:481-5.

17. Allen S, Britton JR, Leonardi-Bee JA. Association between antioxidant vitamins and asthma outcome measures: systematic review and meta-analysis. Thorax 2009;64:610-19.

18. Lee SC, Yang YH, Chuang SY, et al. Reduced medication use and improved pulmonary function with supplements containing vegetable and fruit concentrate, fish oil and probiotics in asthmatic school children: a randomised controlled trial. Br J Nutr 2013;110:145-55.

19. Watson RR, Zibadi $\mathrm{S}$, Rafatpanah $\mathrm{H}$, et al. Oral administration of the purple passion fruit peel extract reduces wheeze and cough and improves shortness of breath in adults with asthma. Nutr Res 2008;28:166-71.

20. Djukanovic R, Roche WR, Wilson JW, et al. Mucosal inflammation in asthma. Am Rev Respir Dis 1990;142:434-57.
21. Garbacki N, Kinet M, Nusgens B, et al. Proanthocyanidins, from Ribes nigrum leaves, reduce endothelial adhesion molecules ICAM-1 and VCAM-1. J Inflamm (Lond) 2005;2:9.

22. Hurst SM, McGhie TK, Cooney JM, et al. Blackcurrant proanthocyanidins augment IFN-gamma-induced suppression of IL-4 stimulated CCL26 secretion in alveolar epithelial cells. Mol Nutr Food Res 2010;54(Suppl 2):S159-70.

23. Park SJ, Shin WH, Seo JW, et al. Anthocyanins inhibit airway inflammation and hyperresponsiveness in a murine asthma model Food Chem Toxicol 2007;45:1459-67.

24. Kim HP, Mani I, Iversen L, et al. Effects of naturally-occurring flavonoids and biflavonoids on epidermal cyclooxygenase and lipoxygenase from guinea-pigs. Prostaglandins Leukot Essent Fat Acids 1998;58:17-24.

25. Shepherd SJ, Gibson PR. Fructose malabsorption and symptoms of irritable bowel syndrome: guidelines for effective dietary management. J Am Diet Assoc 2006;106:1631-9.

26. Nyanhanda T, Gould EM, McGhie T, et al. Blackcurrant cultiva polyphenolic extracts suppress CCL26 secretion from alveolar epithelial cells. Food Funct 2014;5:671-7.

27. Shaw OM, Hurst RD, Harper JL. Boysenberry ingestion supports fibrolytic macrophages with the capacity to ameliorate chronic lung remodelling. Am J Physiol Lung Cell Mol Physiol 2016;311:L628-38. (L-00309-2015R2 in press)

28. Engler RJM, With CM, Gregory PJ, et al. Complementary and alternative medicine for the allergist-immunologist: where do I start? $J$ Allergy Clin Immunol 2009;123:309-16.

29. Taylor DR. Using biomarkers in the assessment of airways disease. J Allergy Clin Immunol 2011;128:927-34.

30. Alving K, Weitzberg E, Lundberg JM. Increased amount of nitric oxide in exhaled air of asthmatics. Eur Respir J 1993;6:1368-70.

31. Kharitonov SA, Yates D, Robbins RA, et al. Increased nitric oxide in exhaled air of asthmatic patients. Lancet 1994;343:133-5.

32. Jatakanon A, Lim S, Kharitonov SA et al. Correlation between exhaled nitric oxide, sputum eosinophils, and methacholine responsiveness in patients with mild asthma. Thorax 1998;53:91-5.

33. Silkoff PE, McClean $\mathrm{P}$, Spino M, et al. Dose-response relationship and reproducibility of the fall in exhaled nitric oxide after inhaled beclomethasone dipropionate therapy in asthma patients. Chest 2001;119:1322-8.

34. Dweik RA, Boggs PB, Erzurum SC, et al. An official ATS clinical practice guideline: interpretation of exhaled nitric oxide levels (FENO) for clinical applications. Am J Respir Crit Care Med 2011;184:602-15

35. van Rensen EL, Straathof KC, Veselic-Charvat MA, et al. Effect of inhaled steroids on airway hyperresponsiveness, sputum eosinophils, and exhaled nitric oxide levels in patients with asthma. Thorax 1999;54:403-8.

36. Juniper EF, O'Byrne PM, Guyatt GH, et al. Development and validation of a questionnaire to measure asthma control. Eur Respir $J$ 1999;14:902-7.

37. Cockcroft D, Killian D, Mellon J, Hargreave F. ATS/ERS recommendations for standardised procedures for the online and offline measurement of exhaled lower respiratory nitric oxide and nasal nitric oxide 2005. Am J Respir Crit Care Med 2005;171:912-30.

38. Miller MR, Hankinson J, Brusasco V, et al. ATS/ERS Task Force. Standardisation of spirometry. Eur Respir J 2005;26:319-38.

39. Marsh S, Aldington S, Williams $\mathrm{M}$, et al. Complete reference ranges for pulmonary function tests from a single New Zealand population. N Z Med J 2006;119:U2281.

40. Dupont LJ, Rochette F, Demedts MG, et al. Exhaled nitric oxide correlates with airway hyperresponsiveness in steroid-naive patients with mild asthma. Am J Respir Crit Care Med 1998;157:894-8.

41. Santanello NC, Zhang J, Seidenberg B, et al. What are minimal important changes for asthma measures in a clinical trial? Eur Respir J 1999;14:23-7.

42. Wenzel S, Holgate ST. The mouse trap: It still yields few answers in asthma. Am J Respir Crit Care Med 2006;174:1173-6; discussion 1176-8.

43. Finkelman FD, Wills-Karp M. Usefulness and optimization of mouse models of allergic airway disease. J Allergy Clin Immunol 2008;121:603-6.

44. Mercer PF, Abbott-Banner K, Adcock IM, et al. Translational models of lung disease. Clin Sci 2015;128:235-56.

45. Persson CGA, Erjefält JS, Korsgren M, et al. The mouse trap. Trends Pharmacol Sci 1997;18:465-7.

46. Kumar RK, Foster PS. Are mouse models of asthma appropriate for investigating the pathogenesis of airway hyper-responsiveness? Front Physiol 2012;3:312. 